\title{
Modelling simultaneous methane and ammonium removal in a one-stage aerobic granular sludge reactor
}

9th IWA Symposium on Systems Analysis and Integrated Assessment Gold Coast, Queensland, Australia

15 June 2015

Celia M. Castro-Barros, Long T. Ho, Mari-K. H. Winkler, Eveline I. P. Volcke 


\section{Concern}

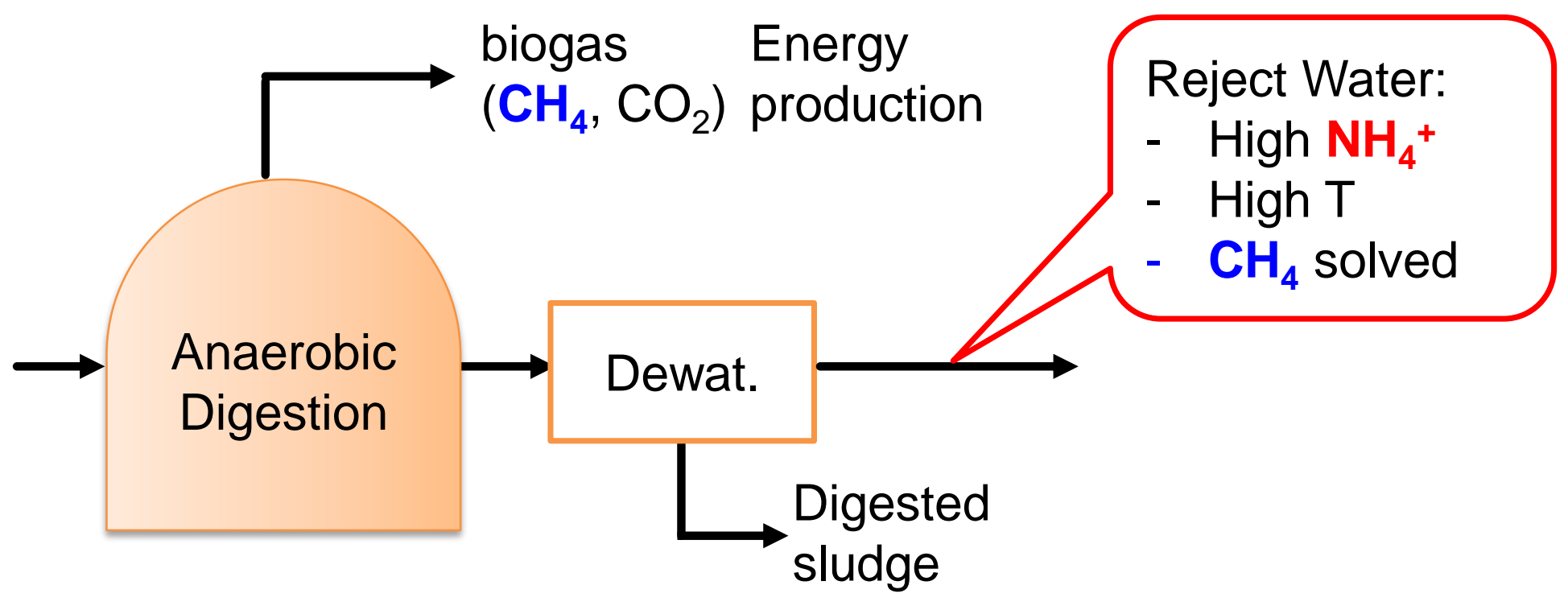

\section{Reject water from anaerobic digestion contains $\mathrm{NH}_{4}{ }^{+}$and $\mathrm{CH}_{4}$}

$\mathrm{NH}_{4}{ }^{+}$

- Eutrophication

- Toxic for living organisms
$\mathrm{CH}_{4}$

- Greenhouse gas (34 $\mathrm{CO}_{2}$ equivalent)

- High impact on global warming 


\section{Removal of $\mathrm{CH}_{4}$ and $\mathrm{NH}_{4}{ }^{+}$}

Nitrite-dependent anaerobic methane oxidation (N-damo)

$$
3 \mathrm{CH}_{4}+8 \mathrm{NO}_{2} \rightarrow 3 \mathrm{CO}_{2}+4 \mathrm{~N}_{2}
$$

could be combined with

Anaerobic ammonium oxidation (anammox)

$$
\mathrm{NH}_{4}{ }^{+}+1.3 \mathrm{NO}_{2} \rightarrow \mathrm{N}_{2}+0.3 \mathrm{NO}_{3}^{-}
$$

$\mathrm{N}$-damo vs. anammox bacteria

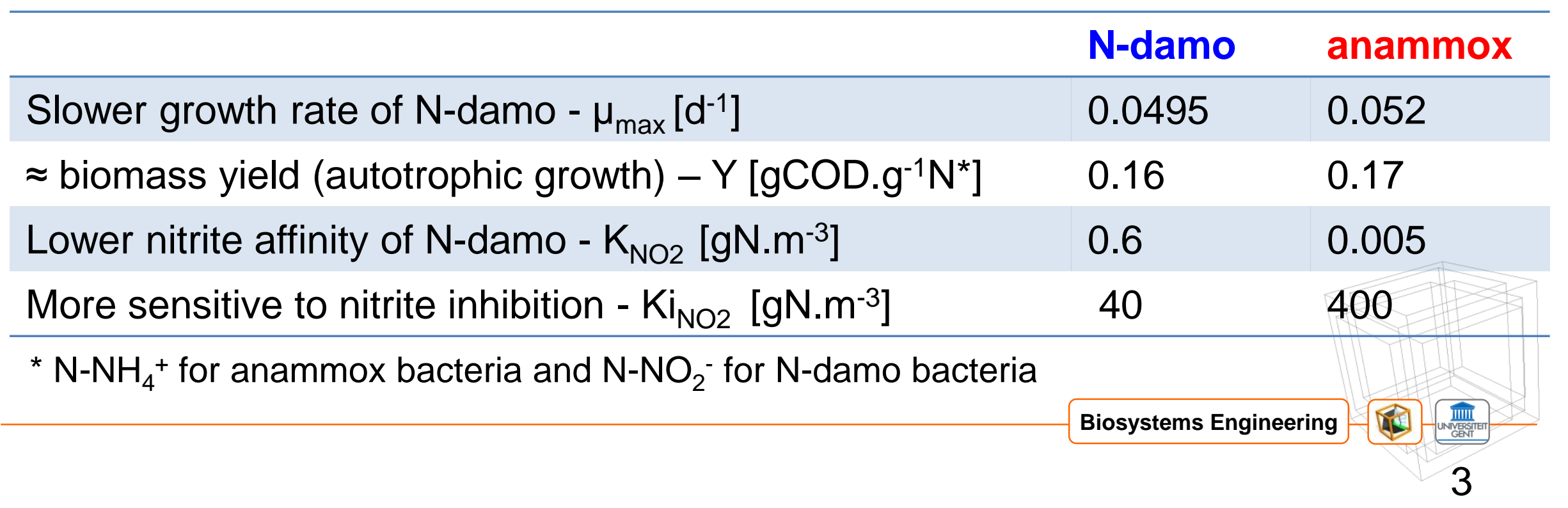




\section{Could we combine $\mathrm{N}$-damo and anammox in NON-AERATED granular sludge reactors to simultaneously remove $\mathrm{CH}_{4}$ and $\mathrm{NH}_{4}{ }^{+}$?}

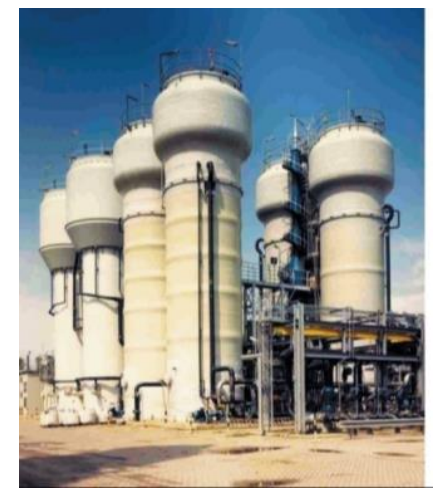

\section{Granular sludge reactors}

- Low footprint

- High SRT

- Different microbial communities 


\section{Could we combine $\mathrm{N}$-damo and anammox in NON-AERATED granular sludge reactors to simultaneously remove $\mathrm{CH}_{4}$ and $\mathrm{NH}_{4}{ }^{+}$?}
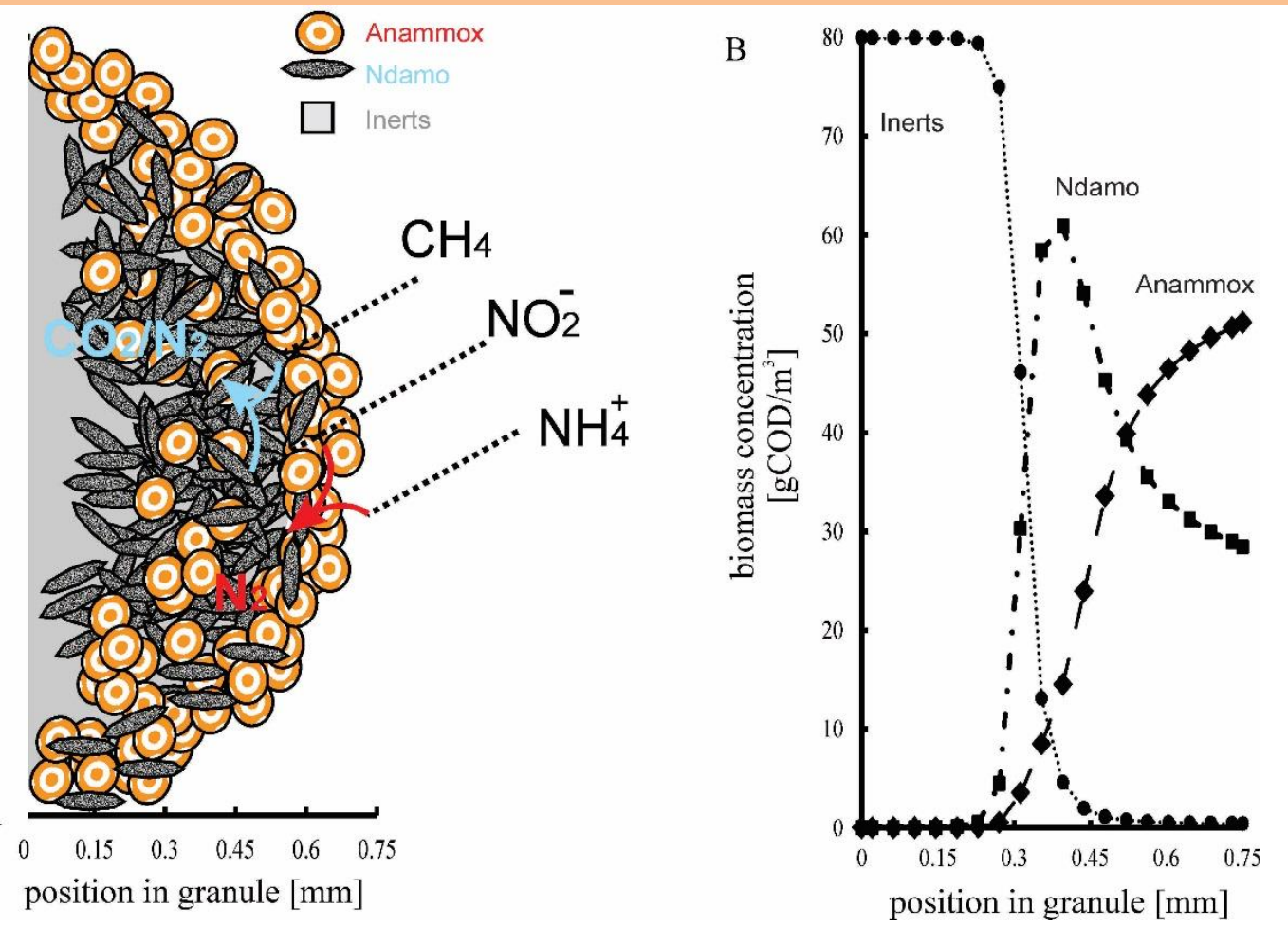

\section{Yes, we can !}

IF

- influent $\mathrm{CH}_{4}: \mathrm{NH}_{4}{ }^{+}: \mathrm{NO}_{2}{ }^{-}$ratio close to stoichiometric

- biomass loading rate sufficiently low

- preferably small granules

Available online at www.sciencedirect.com

ScienceDirect

Winkler et al., Water Research, 2015

journal homepage: www.elsevier.com/locate/watres

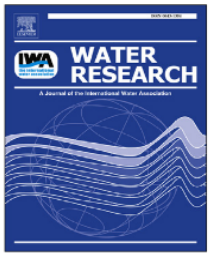

Modelling simultaneous anaerobic methane and ammonium removal in a granular sludge reactor 
Could we combine $\mathrm{N}$-damo and partial nitritation-anammox in AEROBIC granular sludge reactors to simultaneously remove $\mathrm{CH}_{4}$ and $\mathrm{NH}_{4}{ }^{+}$from reject water?

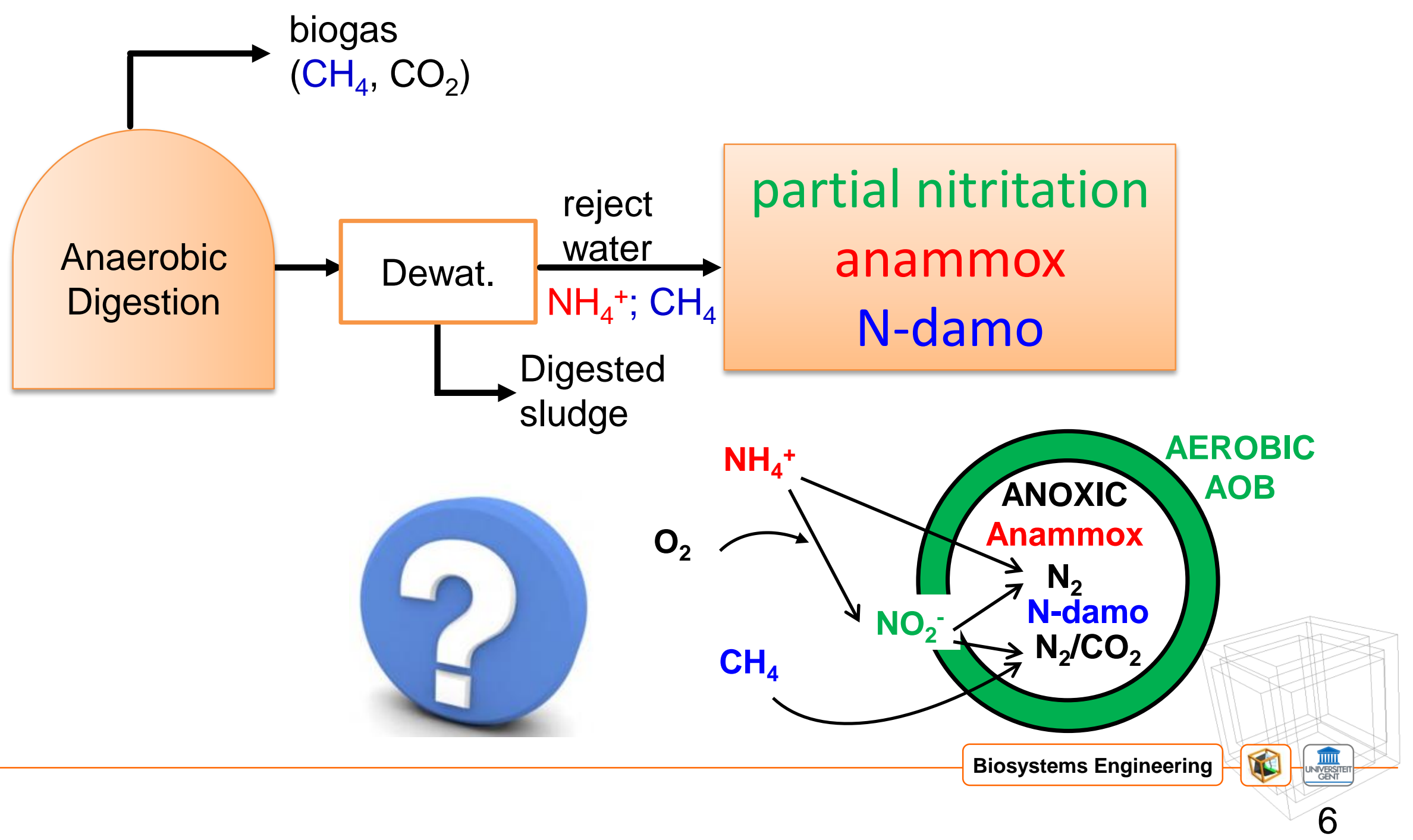




\section{Mathematical model}

One dimensional mathematical model - Aquasim Assessment of bacterial competition in aerobic granules

\begin{tabular}{|c|c|c|c|c|c|}
\hline & $\mathrm{O}_{2}$ & $\mathrm{NH}_{4}{ }_{4}^{+}$ & $\mathrm{NO}_{2}^{-}$ & $\mathrm{CH}_{4}$ & $\mathrm{NO}_{3}^{-}$ \\
\hline $\begin{array}{l}\text { Anammox } \\
\text { bacteria }\end{array}$ & & & & & \\
\hline $\begin{array}{l}\text { N-damo } \\
\text { bacteria }\end{array}$ & & & & & \\
\hline $\begin{array}{l}\text { Anaerobic } \\
\text { Heterot. }\end{array}$ & & & & & \\
\hline AOB & & 0 & & & \\
\hline NOB & & & 0 & & 0 \\
\hline MOB & & & & 0 & \\
\hline $\begin{array}{l}\text { Aerobic } \\
\text { Heterot. }\end{array}$ & & & & & \\
\hline
\end{tabular}


Could we combine $\mathrm{N}$-damo and partial nitritation-anammox in AEROBIC granular sludge reactors to simultaneously remove $\mathrm{CH}_{4}$ and $\mathrm{NH}_{4}{ }^{+}$from reject water?

\section{Scenario analysis}

- Effect of $\mathrm{O}_{2}$ concentration in the bulk liquid

- Effect of influent $\mathrm{NH}_{4}{ }^{+}$concentration

- Biomass distribution in the granules

Most optimistic scenario: $\mathrm{CH}_{4}$ stripping not considered 


\section{Effect of $\mathrm{O}_{2}$ concentration in the bulk liquid}

$\mathrm{NH}_{4}{ }^{+}=300 \mathrm{~g} \mathrm{~N} \cdot \mathrm{m}^{-3}$

$\mathrm{CH}_{4}=100 \mathrm{~g} \mathrm{COD} \cdot \mathrm{m}^{-3}$

Granule size $=0.75 \mathrm{~mm}$

$\mathrm{O}_{2}=0.1-1.5 \mathrm{gO}_{2} \cdot \mathrm{m}^{-3}$

Optimum at

limited $\mathrm{O}_{2}$ concentrations:

\section{$0.2-0.3 \mathrm{gO}_{2} / \mathrm{m}^{3}$}

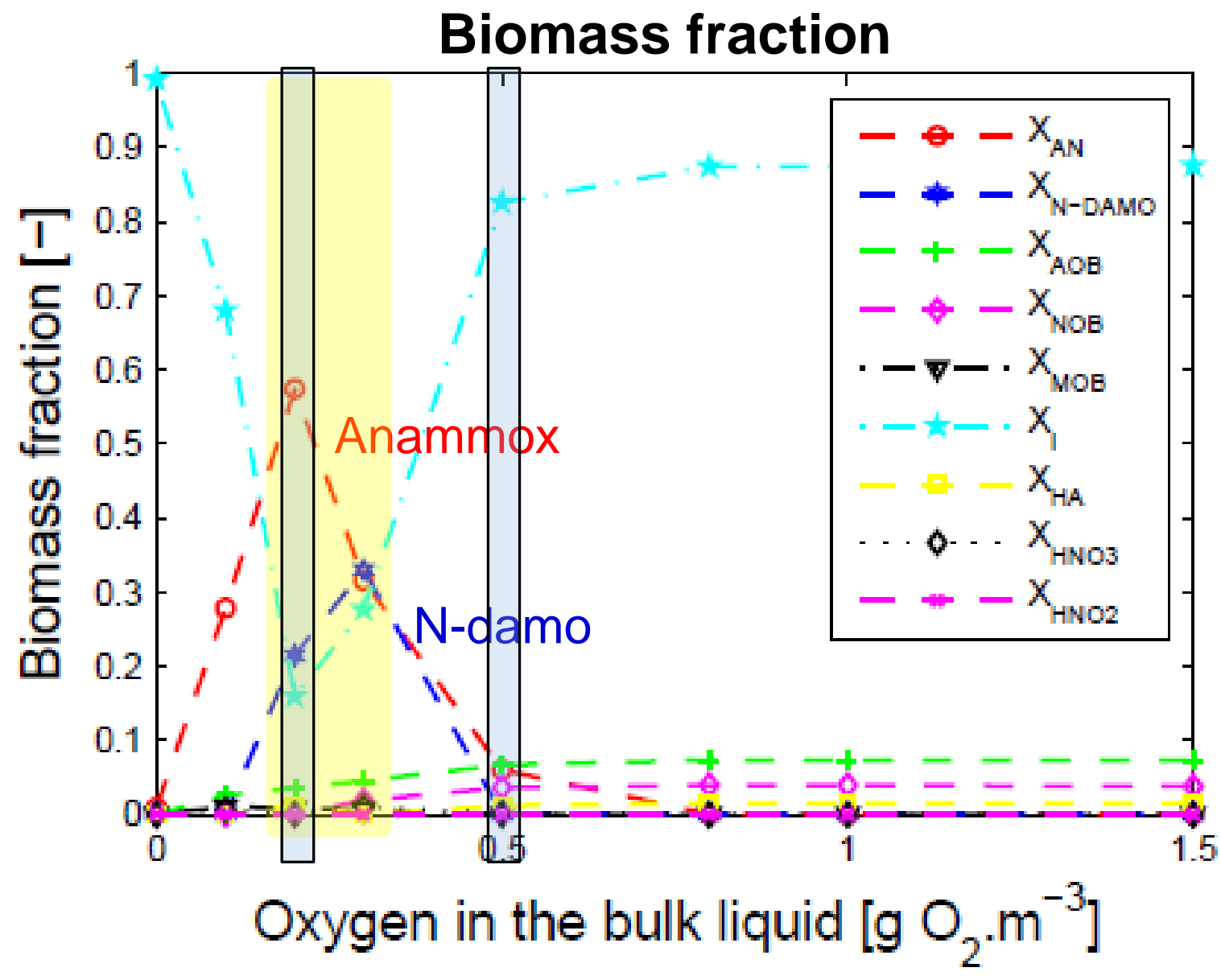

- If higher, anammox and $\mathrm{N}$-damo bacteria inhibited

- If lower, not enough conversion to $\mathrm{NO}_{2}^{-}$ 


\section{Effect of $\mathrm{O}_{2}$ concentration in the bulk liquid}

\section{Substrate concentration}

$\mathrm{NH}_{4}{ }^{+}=300 \mathrm{~g} \mathrm{~N} \cdot \mathrm{m}^{-3}$

$\mathrm{CH}_{4}=100 \mathrm{~g} \mathrm{COD} \cdot \mathrm{m}^{-3}$

Granule size $=0.75 \mathrm{~mm}$

$\mathrm{O}_{2}=0.1-1.5 \mathrm{gO}_{2} \cdot \mathrm{m}^{-3}$

Optimum at limited $\mathrm{O}_{2}$ concentrations:

$0.2-0.3 \mathrm{gO}_{2} / \mathrm{m}^{3}$

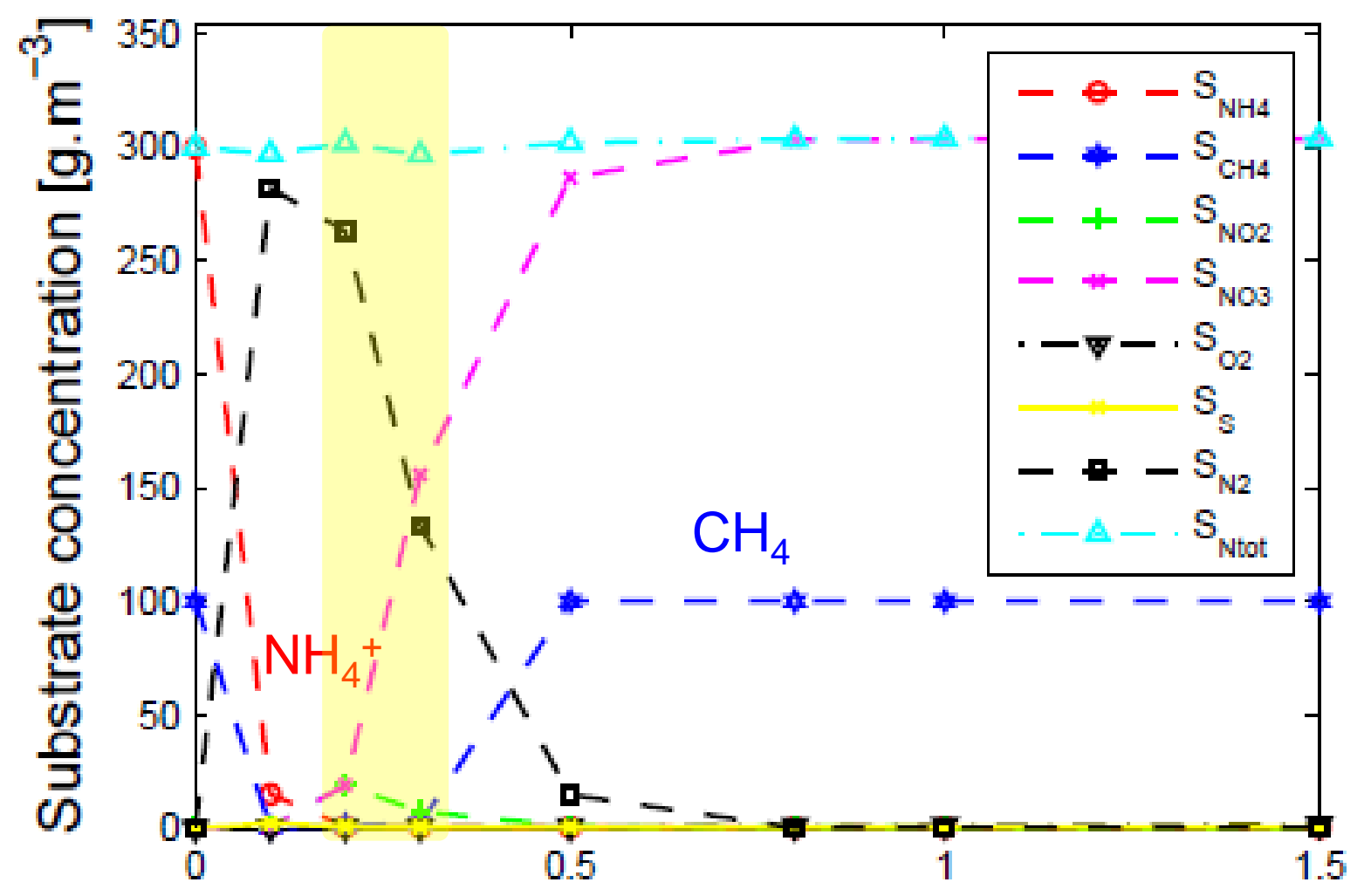

$99 \% \mathrm{CH}_{4}$ removal achieved

Oxygen in the bulk liquid $\left[\mathrm{g} \mathrm{O}_{2} \cdot \mathrm{m}^{-3}\right.$ ] 95\% $\mathrm{N}$ removal achieved 


\section{Effect of influent $\mathrm{NH}_{4}{ }^{+}$concentration}

\section{Biomass fraction}

$\mathrm{NH}_{4}{ }^{+}=\mathbf{1 0 0 - 2 0 0 0 ~ g N . m ^ { - 3 }}$

$\mathrm{CH}_{4}=100 \mathrm{gCOD} \cdot \mathrm{m}^{-3}$

Granule size $=0.75 \mathrm{~mm}$

$\mathrm{O}_{2}=0.2 \mathrm{gO}_{2} \cdot \mathrm{m}^{-3}$

Coexistence of anammox and $\mathrm{N}$-damo:

Influent $\mathrm{NH}_{4}^{+}$

$300-500 \mathrm{gN} / \mathrm{m}^{3}$

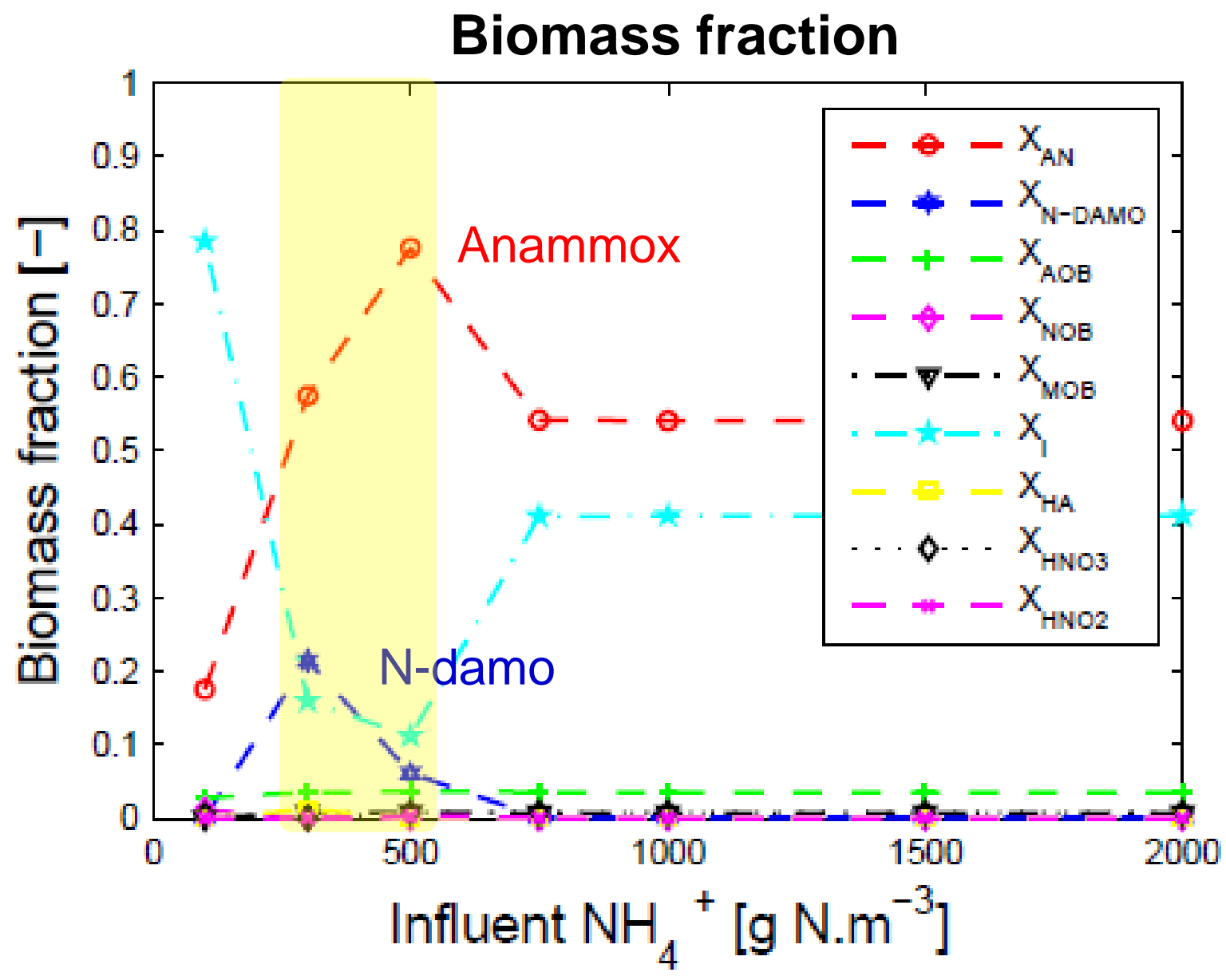

- If higher, anammox bacteria outcompete $\mathrm{N}$-damo bacteria

- If lower, not enough substrate $\left(\mathrm{NH}_{4}{ }^{+}\right.$and $\left.\mathrm{NO}_{2}{ }^{-}\right)$ 


\section{Biomass distribution in the granules}

$\mathrm{NH}_{4}{ }^{+}=300 \mathrm{~g} \mathrm{~N} / \mathrm{m}^{3}$

$\mathrm{O}_{2}=0.2 \mathrm{~g} \mathrm{O}_{2} / \mathrm{m}^{3}$

$\mathrm{CH}_{4}=100 \mathrm{~g} \mathrm{COD} / \mathrm{m}^{3}$

Granule size $=0.75 \mathrm{~mm}$

- Anammox bacteria located closer to the surface area compared to $\mathrm{N}$-damo bacteria

- $\mathrm{AOB}$ dominate the outer oxic part

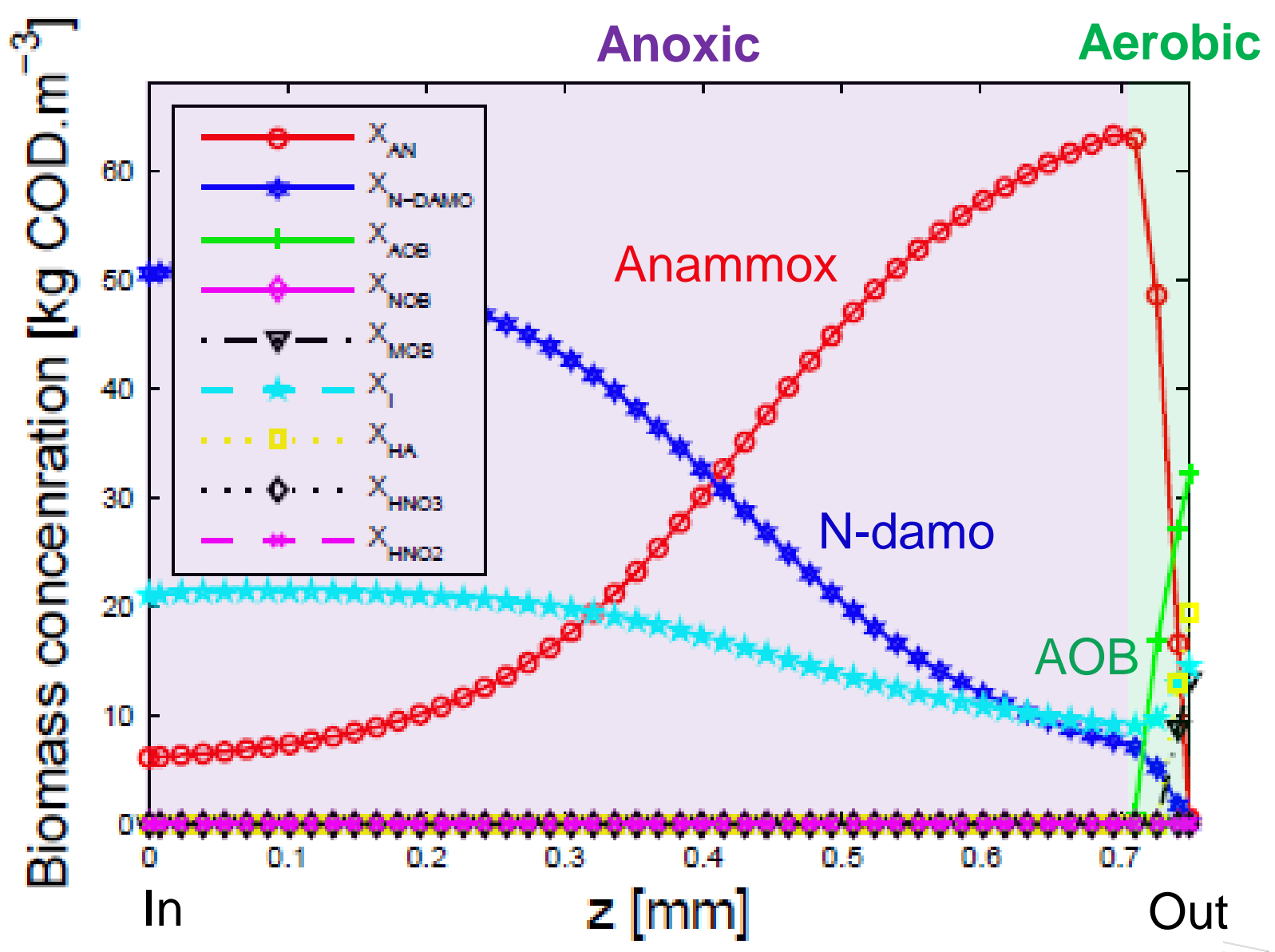

- no $\mathrm{MOB}$ - no aerobic methane oxidation 


\section{Conclusions}

- Simultaneous $\mathrm{NH}_{4}{ }^{+}$and $\mathrm{CH}_{4}$ removal feasible in aerated granular sludge reactors, neglecting $\mathrm{CH}_{4}$ stripping

- Careful control of bulk oxygen concentration required

- high enough for $\mathrm{NH}_{4}{ }^{+}$conversion to $\mathrm{NO}_{2}{ }^{-}$

- low enough to prevent inhibition of $\mathrm{N}$-damo and anammox

- Influent ammonium concentration

- high enough for $\mathrm{NO}_{2}$ - production

- low enough to prevent outcompetition of $\mathrm{N}$-damo 


\section{Thank you for your attention Questions?}

Celia M. Castro-Barros, Long T. Ho, Mari-K. H. Winkler, Eveline I. P. Volcke

The research leading to these results has received funding from the People Program (Marie Curie Actions) of the European Union's Seventh Framework Programme FP7/2007-2013 under REA agreement 289193.

This presentation reflects only the author's views and the European Union is not liable for any use that may be made of the information contained therein. 